\title{
DIGITALIZATION PROCESS IN UKRAINE AS A PREREQUISITE FOR THE SMART CITY CONCEPT DEVELOPMENT
}

\author{
Anna POZDNIAKOVA ${ }^{1}$ \\ National Academy of Sciences of Ukraine, Ukraine
}

\begin{abstract}
The paper aims to review Smart city building process in Ukraine, its successful examples, and possible drawbacks on the way and based on this suggests the steps country should undertake for the future development of this concept. Taking into account that spreading of ICTs (digitalization) plays an important role in laying the foundation for smart solutions' development and usage, we have also provided an overview of this process in Ukraine and compared Ukraine's positions on the global arena. To do this, we have used a number of international indexes (ICT Development Index, Networked Readiness Index, Global Innovation Index, E-Government Development Index, E-Participation Index) to show an objective picture and to cover as many aspects as possible (ICT readiness, ICT usage, ICT skills, and other features build on top of these). Lack of the required infrastructure and equal proper access to ICTs within the country is one of the major issues Ukraine has to deal with right now. We have also compared current positions of Ukraine against the target values specified in the Strategy of Information Society Development of Ukraine-2020. The research is based on the method of theoretical, logical, and systematic analysis of the literature (articles, strategies and agendas, international indexes etc.) along with the methods of comparative analysis that allow comparing smart solutions among the selected cities. We have composed a comparison table for successful smart solutions available currently in Ukraine for the selected cities (Kyiv, Lviv, Kharkiv, Ivano-Frankivsk, Vinnytsia, Dnipro) within different areas. We have also conducted a SWOT-analysis to reveal strong and weak points for the further concept development, as well as the possible consequences and risks. The article suggests the steps for further successful development of smart city concept in Ukraine. These steps should encourage the dialogue on the topic within our country. We believe that cooperation of all stakeholders on the national level is necessary to 1) Establish a common platform for sharing best practices and spreading successful solutions faster; 2) Develop a measurement tool to compare both the progress among different cities and the progress for the specific city within some time period. While locally each city should work on its own Smart City Agenda and Roadmap, ensuring the interests of all groups is taken into account. But of course, active dialogue on both city and national levels, as well as within the axis Government Industry - University - Civil Society is a core component of smart city building process.
\end{abstract}

Key words: digitalization, smart city, smart solution, urban development, ICTs.

JEL Classification: O33, O35, P25, R11

\section{Introduction}

Development of the cities in the XXI century is characterized by the number of trends such as individualism and customization, acceleration of all processes based on the application of ICTs, demographic changes (ageing of population in some countries along with the high birth rates in others), urbanization and migration processes (by 2050 around $70 \%$ of the population will live in cities) etc. Cities encounter a number of urban challenges, such as pollution ( $80 \%$ of $\mathrm{CO} 2$ are produced in cities), congestion, lack and waste of resources, unemployment, poor health systems etc. (PwC, 2005).

Thus, nowadays, many cities worldwide try to find the ways to overcome these challenges aiming to become smart and sustainable. "Smart city" concept, which emerged in 90th, holds an enormous promise here. However, to date, there is no one commonly accepted definition. Typically the term connects ICTs application with economic, social, political, and cultural transformations in cities.

ICTs are widely used for the development; they allow creating more opportunities for the education, citizens' engagement in decision-making, accelerating the flow of information, improving information management and encouraging transparency and accountability etc.

That said, smartness is not only about ICTs usage since ICTs is just a tool on the way to a far-reaching goal - sustainability itself. After studying more than

Corresponding author:

${ }^{1}$ Research Centre for Industrial Problems of Development, National Academy of Sciences of Ukraine.

E-mail: mira37cle@gmail.com 
100 definitions from different sources, ITU (International Telecommunication Union) suggested the following definition foraSmartSustainable City: "ASmartSustainable City is an innovative city that uses ICTs and other means to improve quality of life, efficiency of urban operation and services, and competitiveness, while ensuring that it meets the needs of present and future generations with respect to economic, social, and environmental aspects". They have identified 6 factors that are crucial for smart sustainable cities building and development: smart living, smart people, smart environment and sustainability, smart governance, smart mobility, and smart economy. Right now numerous academic, private and state actors are developing and implementing smart solutions within these 6 areas (ITU-T, 2014).

According to IHS Technology, by 2025 we will have at least 88 smart cities worldwide. They define smart cities as cities that have deployed - or are currently piloting the integration of information, communications, and technology (ICT) solutions across three or more different functional areas of a city (mobile and transport, energy and sustainability, physical infrastructure, governance, safety, and security).

Digital Agenda of Ukraine-2020 identifies "Smart city" as a model based on overwhelming usage of digital technologies to solve current issues of cities, to ensure their sustainable development and to raise citizens' quality of life.

Thus, digitalization process is fairly enough considered as a prerequisite for building smart cities. Current research aims to provide an overview and comparison of ICTs development positions of Ukraine, in particular, in the global market and connected to it opportunities for making Ukrainian cities smarter and more citizenoriented, as well as the suggestion of steps to make the process more efficient. In order to address this aim, the paper sets the following research objectives:

- To review our ICTs development positions in the international market;

- To discuss the worldwide trends in digitization and their impact for Ukraine;

- To review smart solutions that are already presented in Ukraine and compare the availability of smart solutions within 5 selected Ukrainian cities;

- To conduct SWOT-analysis for Smart City concept development in Ukraine;

- To build a cooperation matrix for the main stakeholders and their contributions;

- To suggest steps for further Smart City Concept evolvement in Ukraine.

\section{Digitalization of Ukraine}

Digitalization accelerates economic and social processes, making them more efficient and transparent. Nowadays, IT industry of Ukraine generates around $2-3 \%$ of GDP. One of the major issues Ukraine encounters today is a lack of digitalization, especially in small towns, where this problem is also aggravated by the lack of computer skills/literacy and

Table 1

Indexes measuring ICTs development and readiness of Ukraine

\begin{tabular}{|c|c|c|c|}
\hline Index & Responsible entity & What measures & Ukraine's position \\
\hline $\begin{array}{l}\text { ICT development } \\
\text { index } 2016\end{array}$ & ITU & $\begin{array}{l}\text { (1) ICT readiness (the level of networked infrastructure and access to } \\
\text { ICTs); } \\
\text { (2) ICT use (intensity); } \\
\text { (3) ICT skills. }\end{array}$ & $76 / 175$ \\
\hline $\begin{array}{l}\text { Networked Readiness } \\
\text { Index (NRI) } 2016\end{array}$ & $\begin{array}{l}\text { World Economic } \\
\text { Forum (WEF) }\end{array}$ & $\begin{array}{l}\text { (1) Environment for the technology use and creation (political, } \\
\text { regulatory, business, and innovation); } \\
\text { (2) Networked readiness in terms of ICT infrastructure, affordability, } \\
\text { and skills; } \\
\text { (3) Technology adoption/usage by the three groups of stakeholders } \\
\text { (government, private sector, and individuals); } \\
\text { (4) The economic and social impact of new technologies. }\end{array}$ & $64 / 139$ \\
\hline $\begin{array}{l}\text { Global Innovation } \\
\text { Index (GII) } 2016\end{array}$ & $\begin{array}{l}\text { Cornell University, } \\
\text { INSEAD, World } \\
\text { Intellectual Property } \\
\text { Organization }\end{array}$ & $\begin{array}{l}\text { Innovation Input Sub-Index: } \\
\text { 1.1 Institutions; } \\
\text { 1.2. Human capital and research; } \\
\text { 1.3. Infrastructure; } \\
\text { 1.4. Market sophistication; } \\
\text { 1.5. Business sophistication. } \\
\text { (2) Innovation Output Sub-Index: } \\
\text { 2.1. Knowledge and technology outputs; } \\
\text { 2.1. Creative outputs. }\end{array}$ & $56 / 128$ \\
\hline $\begin{array}{l}\text { E-Government } \\
\text { Development Index } \\
2016 \text { (EGDI) }\end{array}$ & UNO & $\begin{array}{l}\text { (1) Provision of online services, } \\
\text { (2) Telecommunication connectivity, } \\
\text { (3) Human capacity. }\end{array}$ & $62 / 193$ \\
\hline
\end{tabular}


End of Table 1

\begin{tabular}{|c|l|l|l|}
\hline \multirow{2}{*}{$\begin{array}{c}\text { E-Participation Index } \\
2016\end{array}$} & UNO & $\begin{array}{l}\text { (1) E-information: Enabling participation by providing citizens with } \\
\text { public information and access to information without or upon demand; } \\
\text { (2) E-consultation: Engaging citizens in contributions to and } \\
\text { deliberation on public policies and services; } \\
\text { (3) E-decision-making: Empowering citizens through co-design of } \\
\text { policy option and co-production of service components and delivery } \\
\text { modalities. }\end{array}$ & $32 / 191$ \\
\hline
\end{tabular}

Source: compiled by the author, based on: Measuring the Information Society Report 2015, ITU; Networked Readiness Index 2016; UN E-Government Survey 2016

Table 2

Indexes comparison within the selected countries

\begin{tabular}{|l|c|c|c|c|c|}
\hline \multicolumn{1}{|c|}{ Index/Country } & Ukraine & Poland & Germany & Georgia & Russia \\
\hline ICT development index & 5.33 & 6.65 & 8.31 & 5.59 & 6.95 \\
\hline ICT access & 5.58 & 7.09 & 9.09 & 6.29 & 7.23 \\
\hline ICT use & 2.57 & 5.35 & 7.49 & 4 & 5.87 \\
\hline ICT skills & 8.57 & 8.35 & 8.36 & 7.34 & 8.55 \\
\hline EGDI & 0.60 & 0.61 & 0.72 & 0.82 & 0.72 \\
\hline Online Service Index & 0.58 & 0.64 & 0.84 & 0.70 & 0.73 \\
\hline Telecommunication Infrastructure Index & 0.39 & 0.42 & 0.73 & 0.58 & 0.61 \\
\hline Human Capital Index & 0.84 & 0.77 & 0.88 & 0.87 & 0.82 \\
\hline E-participation Index & 0.75 & 0.88 & 0.76 & 0.56 & 0.75 \\
\hline The Networked Readiness Index & 4.17 & 4.50 & 5.55 & 4.25 & 4.54 \\
\hline The Global Innovation Index (GII) & 35.7 & 40.2 & 57.9 & 33.9 & 38.5 \\
\hline
\end{tabular}

Source: compiled by the author, based on: Measuring the Information Society Report 2016, ITU; Networked Readiness Index 2016; UN E-Government Survey 2016

information availability for the citizens. According to the International Telecommunication Union, only $49 \%$ of individuals use the Internet, while only $56 \%$ of households use computers (ITU-T, 2016). Right now there is a $30 \%$ gap in broadband access between the city and village (Digital Agenda of Ukraine, 2016).

We have checked and compared Ukrainian positions in a number of international rankings with the selected countries that have a different level of development (Poland, Georgia, Russia, Germany) to provide a general overview of ICTs development trends, usage, and application among countries. In Table 1, general information about the indexes used and what they are measuring is provided.

The Strategy of Information Society Development in Ukraine-2020 sets the following targets for our country: WEF Networked Readiness Index - 40th place, UN e-Government Index - 50th place, the Global Innovation Index (GII) - 40th place.

A comparison of different indexes and their composites shows that Ukraine has rather poor positions in terms of information telecommunication infrastructure development, our positions are worse than those of Georgia and Russia (see Table 2). But our country has one of the best positions in terms of human capital development and skills, which has to do with the transformations of the national education policy (an increase of government order for ICT specialties), encouragement of public-private partnership, implementation of basic programming class in high school etc.

It is worth mentioning that right now Ukraine is in a situation with the maximum digitalization of international economies by Ukrainian IT companies/ specialists and minimum digitalization of our own economy since many talented developers choose to work for the international market. Moreover, brain drain is a sad tendency in Ukraine since around 10000 IT specialists have already left the country in 2016, while it is estimated that 1 developer generates around 1 million dollars "product" he/she produces, which works for the international market instead of the national one (Digital Agenda of Ukraine, 2016).

Obviously, we cannot talk about successful implementation of smart cities concept till we fully digitalize the country, laying the necessary foundation. Moreover, the country should deal with the digital gap between smaller cities (suburbs) and centres, as well as between people of different ages, backgrounds, incomes etc.

Below, the key drivers of the current stage of digitalization worldwide along with the opportunities and challenges they impose on Ukraine are outlined (Fig. 1). 


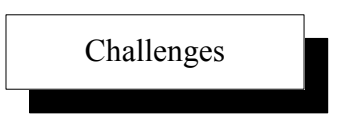

1) Lack of regulations, standards, skills and experience for collection, storage and usage of data;

2) Intellectual property issues;

3) Cyber Security risks;

1) Lack of awareness and experience in this area;

2) Startups are orientated to external market;

4) Lack of professionals and unprepared education system.

1) Lack of the vision, strategy and initiatives to digitalize economy and different areas of life in general; 2) Lack of innovative skills cultivation in schools, universities and economy sectors.

1) Financial barriers for Ukrainian companies that work on international markets (smooth money transfer to accounts opened in Ukraine);

2) Legal obstacles.

1) Lack of legislation for cloud services;

2) Lack of strategy;

3) Lack of the local cloud service providers of the highest security level.

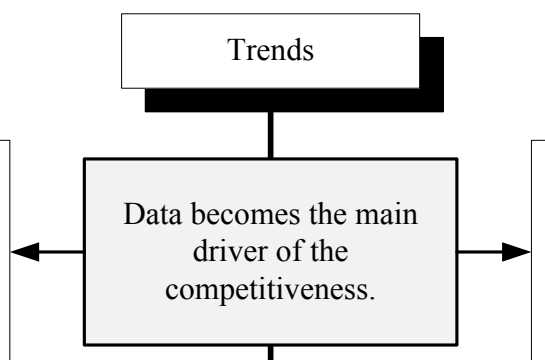

1) Development of new industries;

2) New jobs creation;

3) Establishment of the effective governance and anti-corruption tool.
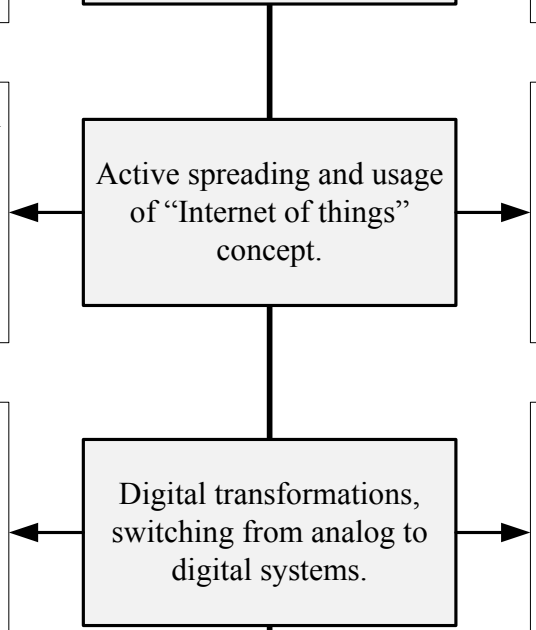

1) Increase of efficiency for many sectors of economy and business processes in general;

2) Investment attraction;

3) Incremental and transformational innovations.

1) Increase of competitiveness of different sectors;

2) Development of digital economy, labor market etc.

3) Spread of innovative entrepreneurship.

1) Easier start for new businesses (no big investments are necessary);

2) Easier launching of internet projects, creation of new market places, expansion of consumer markets for Ukrainian products and services; of new business-models that belong to "shared economy" business model.

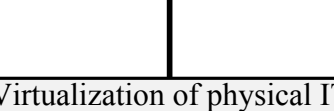

Virtualization of physical IT infrastructure and switching to service models (usage of cloud services and softwaredefined architecture).
1) Fast and cheap way to install and use the necessary digital infrastructure for business/government/society;

2) Effective infrastructure building for the whole country.

Fig. 1. The main trends in the digital world, Ukrainian aspect

Source: compiled by the author, based on: Digital Agenda of Ukraine-2020

\section{Smart Cities of Ukraine}

"Smart city" concept gained its popularity in Ukraine due to a number of reasons - qualified IT specialists that would like to change the country for the better; challenging urbanization problems; intensification of decentralization processes that provide cities with more power in decision-making and desire of simple citizens to live in responsive, resilient and user-friendly cities. Smart Cities are believed to be a tool to improve the quality of services provided to citizens, raise the efficiency, and cut costs of municipalities, contribute to overall economic growth and development.

People in Ukraine yearn for changes and while on the national level, there is still a huge level of uncertainty (economic, social, political, security); on the local level - volunteers, businesses, and city administrations together managed to implement a number of successful smart solutions. This corresponds to the world trend in moving towards "smart city 3.0 " concept, in which citizens are actively involved into the process of development and closely cooperate with public and business sectors.

The concept actively evolves in Kyiv, Kharkiv, Lviv, Vinnytsia, and Dnipro. But around 15 cities of Ukraine nowadays already have relevant projects. Volunteers and creative society are believed to be the main driving force of the concept in Ukraine. The active phase of development took place in 2015 when ICT Competence Centre, iGov (conversion of state services into online format) and ProZorro (public e-procurement system) active groups have emerged. Below we described the 
most prominent and successful initiatives that currently function in Ukraine:

1. Participatory budget - a democratic process that allows every citizen to participate in the distribution of the local budget through the creation of projects to improve the city and/or vote for them. Any resident may submit a project related to the improvement of city life to participate in the competition, win the vote, and watch how the project will be implemented.

2. Open budget - online system that provides a realtime opportunity to all stakeholders to monitor the revenues and expenditures of the city budget, including the spending of public funds. It was launched in 2014; now around 40 cities connected it to their web-sites.

3. iGov - a non-profit, open-source project for providing different administrative services online to cut the bureaucracy and corruption.

Table 3

Smart solutions comparison within 6 Ukrainian cities

\begin{tabular}{|c|c|c|c|c|c|c|c|}
\hline Area & Smart solution & Vinnytsia & Dnipro & Kyiv & Kharkiv & Lviv & $\begin{array}{c}\text { Ivano- } \\
\text { Frankivsk }\end{array}$ \\
\hline \multirow{2}{*}{ Economy } & Interactive map of street kiosks & + & + & + & - & + & - \\
\hline & Public e-procurement system (ProZorro) & + & + & + & + & + & + \\
\hline \multirow{6}{*}{ Mobility } & GPS monitoring of public transport & + & - & + & - & + & + \\
\hline & Electronic scoreboards on transport stops & + & + & - & + & + & + \\
\hline & $\begin{array}{l}\text { Online tool to rate the quality of roads } \\
\text { (Navizor) }\end{array}$ & + & + & + & + & + & + \\
\hline & Smart Traffic lights & - & + & - & - & + & - \\
\hline & E-ticket & - & \multicolumn{5}{|c|}{ In progress } \\
\hline & Parking map & - & + & + & - & - & + \\
\hline \multirow{7}{*}{ Governance } & Contact the mayor & + & + & + & + & + & $\begin{array}{l}\text { beta- } \\
\text { testing }\end{array}$ \\
\hline & Electronic appointment to officials & + & + & + & + & + & \\
\hline & Open budget & + & + & + & + & + & + \\
\hline & Participation budget & + & + & + & In progress & + & + \\
\hline & $\begin{array}{l}\text { Online administrative services (iGov } \\
\text { service) }\end{array}$ & + & + & + & + & + & + \\
\hline & E-petition & + & + & + & + & + & + \\
\hline & E-declaration & + & + & + & + & + & + \\
\hline \multirow{3}{*}{ People } & QR codes for tourists & + & + & + & + & + & + \\
\hline & Electronic tourist guides & + & - & + & + & + & + \\
\hline & WiFi spots & + & + & + & + & + & + \\
\hline \multirow[t]{8}{*}{ Way of living } & Electronic citizen card & + & - & + & - & + & + \\
\hline & Online map of emergency works & + & + & + & + & + & + \\
\hline & Video surveillance system & + & + & + & + & + & + \\
\hline & Bike path & + & - & - & - & + & In progress \\
\hline & $\begin{array}{l}\text { Electronic queue/registration to } \\
\text { kindergarten }\end{array}$ & + & + & + & + & + & + \\
\hline & DonorUA & + & + & + & + & + & + \\
\hline & $\begin{array}{l}\text { Monitoring centre with access and control } \\
\text { for all cameras }\end{array}$ & - & - & + & - & - & - \\
\hline & E-health & \multicolumn{4}{|c|}{ In progress } & + & + \\
\hline \multirow{3}{*}{ Environment } & "Where to hand over the waste" & + & + & + & + & + & + \\
\hline & $\begin{array}{l}\text { Technological project for energy efficiency } \\
\text { (u-Muni) }\end{array}$ & - & - & - & - & + & - \\
\hline & Sorting waste & + & + & + & + & + & + \\
\hline
\end{tabular}

Source: compiled by the author, based on the web-sites of Kharkiv, Dnipro, Kyiv, Lviv, Vinnytsia, Ivano-Frankivsk municipalities
4. U-muni - system for the optimization of energy costs, which is designed primarily for businesses, office buildings, and municipalities. Heads of agencies using the system can quickly collect data on resource consumption in buildings, deeply analyse the effectiveness of their use and quickly respond to anomalies. For municipalities, the company provides 1 year preferential subscription period free of charge.

5. Navizor - service that allows rating the quality of roads and planning your trip in the best way, taking into account the pitfalls.

6. E-health - a system, which aims to ease the access to medical services for patients and data processing and handling for doctors. Partly, using different providers, this already works in several Ukrainian cities but works on the establishment of the unified platform are still underway. 
7. E-petition - a service allows simple citizens to reach the City Council with their initiatives. Thus, in case of receiving $\mathrm{N}$ number of signatures within $\mathrm{N}$ days, the responsible officials from the City Council should consider initiative and official response should be issued.

8. Access to the truth (Dostup.pravda) - a platform to submit an e-request for the access to public information, was launched in 2014 by civic organization Centre UA. All the requests automatically become publicly available, as well as the answers to them.

9. The online platform of informal education in Ukraine - any registered provider can leave information about courses, master-classes within different regions of Ukraine, and any user may filter the available possibilities per his/her needs. It was launched in 2017.

10. "Rozumne misto" platform - a nationwide internet-platform for e-governance and e-democracy to be applied to mature communities, as well as a great tool for the cooperation between state, business and civil society sectors. The project includes a set of microservices that easily can be adapted and applied to any of the cities. Right now the system includes 729 towns; around 80 of them use different modules. The project includes 11 modules: mapping housing and communal service defects, e-petition service, administrative e-services integrated with iGov, open finances information integrated with E-data, open budget, smart apartment building co-owners association, which includes warm, comfortable, and energy-efficient buildings etc., medicine database, e-procurement, blood donation service, city news and surveys.

We have built a comparative table to show the developed and implemented smart solutions among the Ukrainian cities that are believed to be flagmans of the movement.
There are other numerous innovative solutions that are applied in different cities of Ukraine - in Kyiv, there is a street that is supposed to be a testbed for smart solutions application and cooperation between IT service providers, civil society and city administration (Melnykova Smart Street); Kropyvnytskyi city - the first city to launch smart lights system by Owlet, innovative city within city in Kyiv - "UNIT CITY" project, IvanoFrankivsk created a platform to enhance accessibility for people with disabilities "Accessible Ivano-Frankivsk", establishment of city dashboard with statistics in Lviv etc.

It is planned to launch IoT in cooperation with Cisco next year and cover the country with not expensive sensors to monitor free parking spaces, garbage bins filling etc.

Below we have summarized the main strengths and weaknesses Ukraine possesses on the way of Smart City concept development and implementation (see Table 4).

Active cooperation between all stakeholders plays a crucial role during the process; we have built a cooperation matrix for the main actors, outlining their core contributions to the process (Fig 2). Academic sector is presented by various research institutions and universities; Industry - interested companies (more often in IT sector) that play a role of testbeds (Google, Microsoft, Huawei etc.) and also possess financial resources; Government sector - different state institutions, agencies and officials, e.g. State Agency of e-Government of Ukraine, State Informatization Agency, Municipalities, Committees etc.; Third Sector includes civil society that engages in co-creation of Smart sustainable Cities (iGov, ProZorro group, Rozumne misto and etc.), as well as simple citizens that create the demand and provide a feedback for the smart solutions implemented.

Table 4

SWOT-analysis for the Smart City concept development in Ukraine

\begin{tabular}{|c|c|c|}
\hline & Positive & Negative \\
\hline Internal & $\begin{array}{l}\text { STRENGTHS } \\
\text { 1) Profound amount of creative and talented activists and } \\
\text { volunteers; } \\
\text { 2) Highly-qualified IT specialists; } \\
\text { 3) Good computer literacy level among citizens; } \\
\text { 4) A society ready and willing for changes. } \\
\text { 5) Demand for making cities smarter and more user-friendly. }\end{array}$ & $\begin{array}{l}\text { WEAKNESSES } \\
\text { 1) Lack of holistic approach both on the city and state levels; } \\
\text { 2) Lack of proper ICT infrastructure, security systems, } \\
\text { identification tools etc.; } \\
\text { 3) Lack of the needed skills and qualified personnel on the } \\
\text { executive level; } \\
\text { 4) Lack of financial resources and lack of studied best } \\
\text { practices applied worldwide. }\end{array}$ \\
\hline External & $\begin{array}{l}\text { OPPORTUNITIES } \\
\text { 1) Active development of start-ups movement; } \\
\text { 2) Spreading of "shared economy" ideas; } \\
\text { 3) New business market opportunities; } \\
\text { 4) Citizen-centric governance establishment; } \\
\text { 5) Cut of bureaucracy and corruption on the city level; } \\
\text { 6) Active cooperation with foreign cities, best practices } \\
\text { exchanges, and common cooperation platforms } \\
\text { establishment. }\end{array}$ & $\begin{array}{l}\text { THREATS } \\
\text { 1) Disintegration of national digital system due to the } \\
\text { establishment of separate data centres, identification systems, } \\
\text { development of individual strategies and policies within } \\
\text { individual cities etc.; } \\
\text { 2) Confusing simple automatization process with real } \\
\text { smartization in cities; } \\
\text { 3) Information security and privacy issues; } \\
\text { 4) Shifting final focus from the "person" to "profit". }\end{array}$ \\
\hline
\end{tabular}

Source: made by the author 


\begin{tabular}{|c|c|c|c|c|}
\hline & Academic sector & Industry & Government & Third Sector \\
\hline $\begin{array}{l}\text { Academic } \\
\text { sector }\end{array}$ & $\begin{array}{c}\text { Intellectual } \\
\text { capital. }\end{array}$ & $\begin{array}{l}\text { Implementation } \\
\text { of ideas and } \\
\text { developments } \\
\text { in real testbeds. }\end{array}$ & $\begin{array}{l}\text { Providing } \\
\text { incentives and } \\
\text { support to } \\
\text { research } \\
\text { institutions. }\end{array}$ & $\begin{array}{c}\text { Information } \\
\text { exchange, } \\
\text { Feedback receiving, } \\
\text { Spreading the } \\
\text { information. }\end{array}$ \\
\hline Industry & $\begin{array}{c}\text { Ideas, } \\
\text { High-quality } \\
\text { specialists, } \\
\text { Theoretical } \\
\text { background. }\end{array}$ & $\begin{array}{c}\text { Financial } \\
\text { capital. }\end{array}$ & $\begin{array}{l}\text { Prioritization of } \\
\text { citizens needs vs } \\
\text { pure profit } \\
\text { component. }\end{array}$ & $\begin{array}{c}\text { Monitoring, } \\
\text { Testing, } \\
\text { Raising awareness. }\end{array}$ \\
\hline $\begin{array}{l}\text { Government } \\
\text { IIIII }\end{array}$ & $\begin{array}{c}\text { Theoretical } \\
\text { background, } \\
\text { High-quality } \\
\text { resources, } \\
\text { Analysis and } \\
\text { expediency. }\end{array}$ & $\begin{array}{c}\text { Mass } \\
\text { implementation } \\
\text { of new } \\
\text { technologies, } \\
\text { Financing, } \\
\text { Effectiveness }\end{array}$ & $\begin{array}{l}\text { Regulations and } \\
\text { standards. }\end{array}$ & $\begin{array}{c}\text { Monitoring, } \\
\text { Sharing concerns. }\end{array}$ \\
\hline $\begin{array}{l}\text { Third } \\
\text { Sector } \\
\text { Tivi }\end{array}$ & $\begin{array}{l}\text { Cooperation on } \\
\text { solutions } \\
\text { development and } \\
\text { analysis of } \\
\text { needs. }\end{array}$ & $\begin{array}{l}\text { Possibilities to } \\
\text { implement } \\
\text { solutions and } \\
\text { improve the life } \\
\text { of citizens. }\end{array}$ & $\begin{array}{c}\text { Guarantees and } \\
\text { protection. }\end{array}$ & $\begin{array}{l}\text { Monitoring, } \\
\text { Ideas generation, } \\
\text { Demand forming, } \\
\text { Raising awareness. }\end{array}$ \\
\hline
\end{tabular}

Fig. 2. Main actors cooperation matrix

Source: compiled by author, based on Deakin, M. Triple Helix (2014)

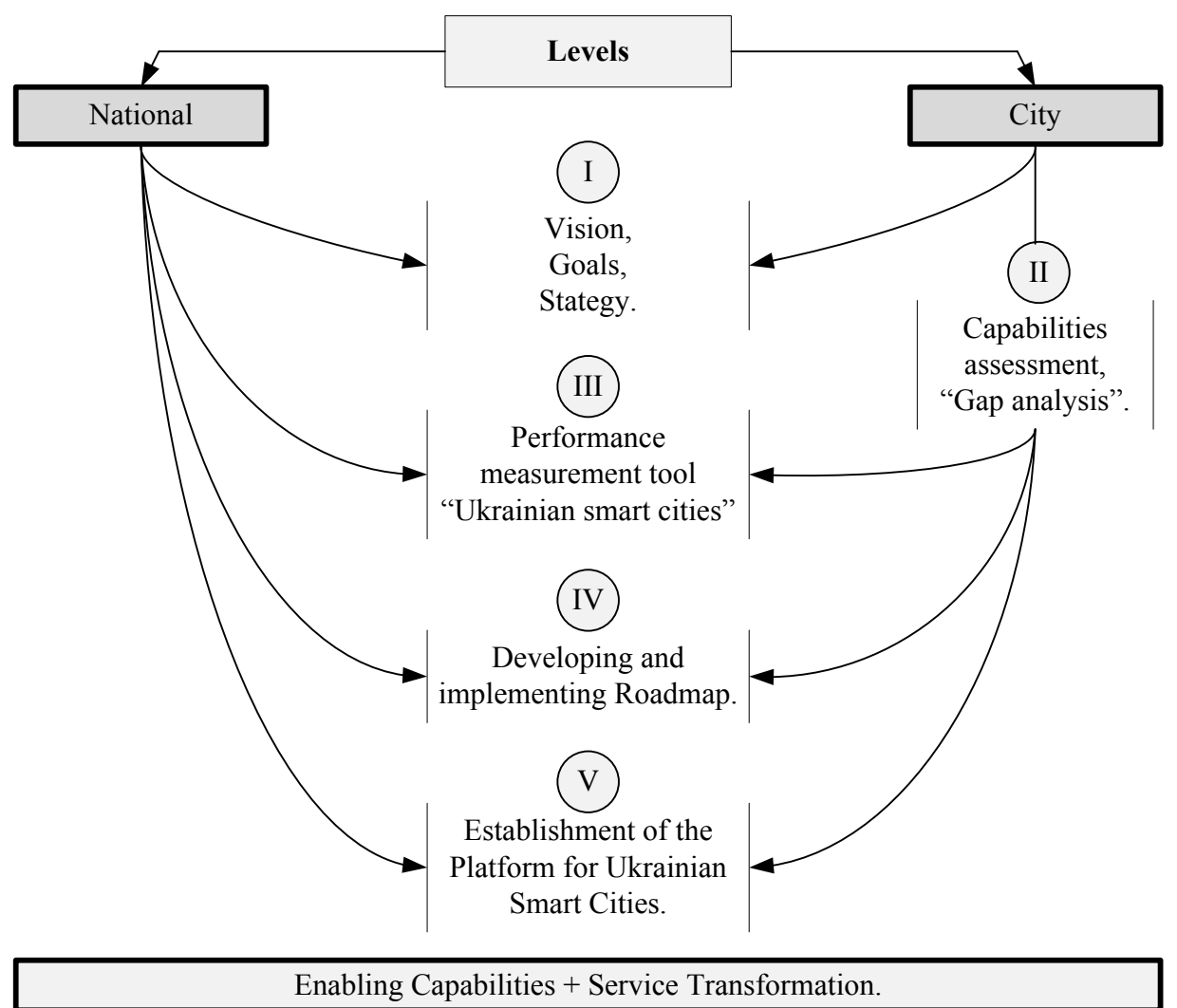

Fig. 3. The algorithm to make cities smarter

Source: compiled by the author, based on Making cities smarter, BSI 
BSI (British Standards Institution) has developed a route to a Smarter City establishment, which can be applied in Ukraine with some adjustments (see Fig. 3).

It is important to begin with a common vision and strategy, common within the country but with some particularities in specific cities. After this, each city is to conduct an analysis of its capabilities, strong points, weaknesses, and threats. During the next stage, performance measurement tool should be created in cooperation with other cities and coordination on a state level, in order to check the progress and to compare cities with each other. Each city should develop its own roadmap that after the implementation will allow realizing the potential of the cities to the fullest and changing the way services are provided and consumed. Moreover, it is important within the whole process to have established a common platform for Ukrainian Smart Cities to share best practices, organize roundtables and conferences etc.

Among the 6 cities we selected for the smart solutions comparison, we found only 1 city (Kyiv) that possesses Smart City Agenda (developed in 2015) and only 2 cities that have Digital Transformation Agendas (Lviv and Dnipro), other cities have a common development strategy but we failed to find separate agendas for the digitalization or smartization processes of regions.

Currently Ukrainian cities, unfortunately, do not take part in any international rankings of Smart and Sustainable Cities. We also do not have a holistic and overwhelming approach to measure the progress of cities within our country. But some first successful steps on the way include:

1) Ranking of comfortable cities in Ukraine, 2016 by Focus.ua group. The research covers 22 cities and 4 main categories:

- Economy (Level of average salary, Consumers Price Index, Housing prices, Renting prices, the Ratio of resumes to vacancies, Investment attractiveness of city);

- Safety (Overall level of crime, Level of serious crimes, Level of terrorist threat);

- Transport infrastructure (Number of air connections, Number of railway connections, Number of roads with international and national importance),

- Environment (Air pollution, Level of dangerous waste),

- Public opinion on the quality of city services and the most comfortable city in Ukraine.

- Leading cities include Lviv, Kyiv, Khmelnytskyi, Vinnytsia, Lutsk, Ivano-Frankivsk, Ternopil, Uzhhorod, Kharkiv, Rivne.
2) Transparent cities ranking, 2017 by Transparency International. Measures the transparency of the hundred largest cities and develop a local government transparency ranking. All cities are measured by 91 indicators according to 13 areas: Information about the work of municipal authorities; Public participation; Public procurement policy; Housing policy; Budgeting and public contracts; Grants and funding; Social services; Human resources; Professional ethics and conflict of interests; Land use and construction policy; Municipal businesses; Municipal property; Education (Transparency International, 2017).

The top-5 leading cities include: Lviv, Kropyvnytskyi, Ivano-Frankivsk, Mykolaiv, Kyiv. However, both systems have their drawbacks, like the lack of holistic approach and measuring only particular areas, they do not measure dynamically on a constant basis, ignore small cities etc.

\section{Conclusions}

Ukrainian cities have recently joined the global movement for the smart sustainable cities' development and shifting responsibilities and powers from the centre to the cities. We do have many successful examples already implemented on the basis of active cooperation between civil society, industry, and government sector.

Among the hindering factors, we can outline: digital gap along with skills gap among the rural and urban areas, lack of best practices exchange on the municipal level between different cities, low financing etc.

But at the same time, positions of Ukraine on the international arena demonstrate the availability of highly qualified human resources that can be a foundation for future successful developments. The country should create conditions to avoid brain drain of specialists and encourage them to invest and rebuild their own country and cities.

The work on both local and national levels is necessary to establish a dialogue platform for cities, as well as to introduce a measurement tool for progress. An active role of all stakeholders is anticipated since they contribute in different domains: academic sector provides think tank forces; industries possess financial capital; the third sector is good in ideas generation, awareness raising and forming the demand for the most needed solutions. And on top of this government sector is responsible for monitoring, standards development and security questions. 


\section{References:}

Cities of the future. (2005). Electronic resources. Retrieved 15 October 2017 from: https://www.pwc.com/gx/ en/government-public-sector-research/pdf/cities-final.pdf

ITU-T Focus Group on Smart Sustainable Cities. (2014). Smart sustainable cities: An analysis of definitions. Electronic resources. Retrieved 15 October 2017 from: http://www.itu.int/en/ITU-T/focusgroups/ssc/Pages/ default.aspx

Smart Cities to Rise Fourfold in Number from 2013 to 2025. (2014). IHS Markit. Electronic resources. Retrieved from: http://news.ihsmarkit.com/press-release/design-supply-chain-media/smart-cities-rise-fourfoldnumber-2013-2025

Measuring the Information Society Report, ITU (2015). Electronic resources. Retrieved from: http://www.itu.int/en/ITU-D/Statistics/Documents/publications/misr2015/MISR2015-w5.pdf.

Networked Readiness Index, WEF. (2016). Electronic resources. Retrieved from: http://reports.weforum.org/ global-information-technology-report-2016/networked-readiness-index/

UN E-Government Survey, UNO. (2016). Electronic resources. Retrieved from: http://workspace.unpan.org/ sites/Internet/Documents/UNPAN96407.pdf

Digital Agenda-2020, Ministry of Economic Development and Trade of Ukraine. (2016). Electronic resources. Retrieved from: http://www.ht-office.org/digital-agenda/

E-health systems of Ukraine. Electronic resources. Retrieved from: https://medics.com.ua/ http://ehealth.com.ua/about.

Access to the truth. Electronic resources. Retrieved from: dostup.pravda.com.ua

Online platform for non-formal education. Electronic resources. Retrieved from: https://learnlifelong.net/ platform

Smart city project. Electronic resources. Retrieved from: http://www.rozumnemisto.org/index/

Smart and smarter: innovations in Ukrainian cities. (2016). Electronic resources. Retrieved from: https://delo.ua/ ukraine/umnye-i-esche-umnej-kakimi-innovacijami-mogut-pohvastatsja-ukrai-326548/

Kyiv Smart City 2020. (2015). Electronic resources. Retrieved from: http://www.kyivsmartcity.com/

Kropyvnytsky installs Ukraine's first smart street lighting. (2017). Electronic resources. Retrieved from: https://www.kyivpost.com/technology/kropyvnytsky-installs-ukraines-first-smart-street-lighting.html

UNIT.CITY project. Electronic resources. Retrieved from: http://unit.city/2/

Making cities smarter, BSI. (2015). Electronic resources. Retrieved from: https://www.bsigroup.com/LocalFiles/ en-GB/smart-cities/resources/BSI-Making-cities-smarter-Guide-for-city-leaders-UK-EN.pdf

Deakin, M. (2014) Smart cities: the state-of-the-art and governance challenge. Triple Helix. (2014) 1: 7. doi: 10.1186/s40604-014-0007-9

Comfortable cities ranking. (2016). Electronic resources. Retrieved from: https://focus.ua/ratings/359647/

Building Transparent Cities. (2017). Electronic resources. Retrieved from: https://ti-ukraine.org/en/projects/ policy-analysis/building-transparent-cities/

Digital Transformation Agenda of Lviv city. (2016). Electronic resources. Retrieved from: http://www8.city-adm.lviv.ua/inTEAM/Uhvaly.nsf/(SearchForWeb)/F5AAAA4163C74BBEC2257F7E0052E 61F?OpenDocument

Regional informatization program "Electronic Dnipro". (2016). Electronic resources. Retrieved from: http://decentralization.gov.ua/pics/upload/311-d3aee2c6d6c04f325ab07521a92a7890.pdf

\section{Анна ПОЗДНЯКОВА}

ПРОЦЕСС ДИГИТАЛИЗАЦИИ» УКРАИНЫ КАК ПРЕДПОСЫЛКА ДЛЯ РАЗВИТИЯ КОНЦЕПЦИИ УМНЫХ ГОРОДОВ

Аннотация. Целью статьи является рассмотрение процесса построения умных город в Украине, успешных примеров и возможных проблем на данном пути. На основе данного анализа предлагаются шаги для будущего развития концепции в Украине. Принимая во внимание, что распространение ИКТ (дигитализации) играет важную роль в закладывании основ для разработки и использования умных решений, мы также приводим обзор данного процесса в Украине и сравниваем ее позиции на мировой арене. Для данного анализа мы используем ряд международных индексов (Индекс развития ИКТ, Индекс Сетевой готовности, Мировой инновационный индекс, Индекс е-управления, Индекс е-участия) чтобы показать объективную картину и охватить как можно больше аспектов (ИКТ готовность, использование, навыки, а также дополнительные аспекты, базирующиеся на них). Нехватка инфраструктуры необходимого качества и равного доступа к ИКТ в рамках страны является одной из основных проблем, которая требует решения в нашей стране на данный момент. Мы также сравнили текущие позиции Украины с целевыми показателями, которые отмечены 
Vol. 3, No. 4, 2017

в Стратегии развития информационного общества Украины-2020. В исследовании используются методы теоретического, логического и систематического анализа информации (статей, стратегий и концепции, международных индексов), наряду с методами сравнительного анализа, которые позволяют сопоставить умные решения среди выбранных городов. Мы составили сравнительную таблицу для успешных умных решений, которые на данный момент присутствуют в Украине для выбранных городов (Киев, Львов, Харьков, Ивано-Франковск, Винница, Днепр) в разных секторах. Был проведен SWOT анализ с целью определить сильные и слабые факторы развития концепции, а также возможные риски. В статье предложены последующие шаги, необходимые для успешного развития концепции умных городов в Украине. Мы верим, что кооперация всех заинтересованных сторон на национальном уровне необходима для 1) Создания общей платформы лучших практик и обмена опытом; 2) Создания инструмента отслеживания прогресса разных городов, а также динамического прогресса для отдельных городов в течении определенного временного интервала. В тоже время на местах городам рекомендуется разработать стратегию умного города и дорожную карту развития, принимая во внимания интересы всех групп. Активный диалог как на национальном, так и на местном уровнях, а также в рамках оси Государственный сектор - Бизнес - Академический сектор Гражданское общество является основным компонентом построения умных городов в Украине. 